\title{
CDH1 Gene Mutation Negative
}

National Cancer Institute

\section{Source}

National Cancer Institute. CDH1 Gene Mutation Negative. NCI Thesaurus. Code

C160350.

A genetic finding indicating that $\mathrm{CDH} 1$ gene mutations have not been detected in a sample. 